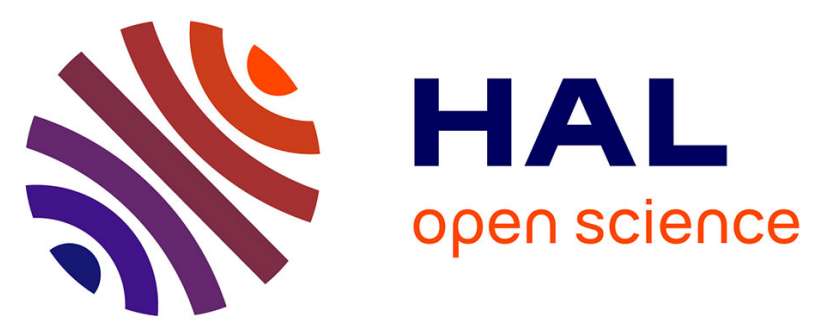

\title{
Effects of rutin and quercetin on monooxygenase activities in experimental influenza virus infection.
}

Varban M Savov, Angel S Galabov, Lyubka P Tantcheva, Milka M Mileva, Elitsa L Pavlova, Emilia S Stoeva, Ana A Braykova

\section{- To cite this version:}

Varban M Savov, Angel S Galabov, Lyubka P Tantcheva, Milka M Mileva, Elitsa L Pavlova, et al.. Effects of rutin and quercetin on monooxygenase activities in experimental influenza virus infection.. Experimental and Toxicologic Pathology, 2006, 58 (1), pp.59-64. 10.1016/j.etp.2006.05.002 . pasteur00736404

\section{HAL Id: pasteur-00736404 https://hal-riip.archives-ouvertes.fr/pasteur-00736404}

Submitted on 28 Sep 2012

HAL is a multi-disciplinary open access archive for the deposit and dissemination of scientific research documents, whether they are published or not. The documents may come from teaching and research institutions in France or abroad, or from public or private research centers.
L'archive ouverte pluridisciplinaire HAL, est destinée au dépôt et à la diffusion de documents scientifiques de niveau recherche, publiés ou non, émanant des établissements d'enseignement et de recherche français ou étrangers, des laboratoires publics ou privés. 


\title{
Effects of rutin and quercetin on monooxygenase activities in experimental influenza virus infection
}

\author{
Varban M. Savova, Angel S. Galabov ${ }^{\mathrm{b}}$, Lyubka P. Tantcheva ${ }^{\mathrm{c}}$, Milka M. Mileva ${ }^{\mathrm{d}}$, \\ Elitsa L. Pavlova ${ }^{\mathrm{a}, *}$, Emilia S. Stoeva ${ }^{\mathrm{c}}$, Ana A. Braykova ${ }^{\mathrm{e}}$ \\ ${ }^{a}$ Medical Physics, Faculty of Physics, Sofia University "St. Kliment Ohridski”, 5 James Boucher Blvd., 1164 Sofia, Bulgaria \\ 'Institute of Microbiology "Stefan Angelov", Bulgarian Academy of Sciences, Sofia, Bulgaria \\ ${ }^{\mathrm{c}}$ Institute of Physiology, Bulgarian Academy of Sciences, Sofia, Bulgaria \\ ${ }^{\mathrm{d}}$ Medical University of Sofia, Sofia, Bulgaria \\ ${ }^{\mathrm{e}}$ Institute of Molecular Biology, Bulgarian Academy of Sciences, Sofia, Bulgaria
}

Received 2 February 2006; accepted 9 May 2006

\begin{abstract}
The aim of this work is to study the effect of the flavonoids rutin and quercetin on hepatic monooxygenase activities in experimental influenza virus infection (EIVI). EIVI causes oxidative stress in the whole organism. This is confirmed by the rapidly increased concentrations of thiobarbituric reactive substances in influenza-infected mice: lungs - 290\%; blood plasma - more than $320 \%$; liver $-230 \%$; brain - 50\%. Although known for their antioxidant activities, rutin and quercetin exhibit prooxidant effect in healthy and antioxidant activity in influenza-infected animals. The pretreatment with both flavonoids $(20 \mathrm{mg} / \mathrm{kg}$ b.w.) restores oxidative damage mostly in the target organ of the infection as well as in the liver of all infected mice (lungs: rutin $-30 \%$, quercetin $-40 \%$, combination $-45 \%$; liver: rutin $-12 \%$; quercetin $-40 \%$; combination $-50 \%$ ). As far as EIVI causes oxidative stress, toxicosis and inhibition of the hepatic monooxygenase activity, it is important to study the effects of rutin and quercetin on these systems. Both flavonoids induce the level of cytochrome P-450 (rutin $-13 \%$, quercetin $-30 \%$, combination $-22 \%$ ) but inactivate NADPH-cytochrome $c$ reductase, aminopyrine $N$-demethylase and analgin $N$-demethylase on the 5 th day of EIVI. Probably, these flavonoids affect different components of the monooxygenase system. These effects could be explained with oxidative hepatic intoxication on the 5th critical day of EIVI as well as higher dose treatment. More data are needed on the antioxidant/prooxidant effects of rutin and quercetin, probably due to specific metabolic and physiological activities, chemical structure, etc.
\end{abstract}

(C) 2006 Elsevier GmbH. All rights reserved.

Keywords: Influenza; Monooxygenase activity; Oxidative stress; Rutin; Quercetin

\footnotetext{
${ }^{*}$ Corresponding author. Tel.: +359887982172 ; fax: +35929625276 .

E-mail address: elli_pavlova@abv.bg (E.L. Pavlova).
}

\section{Introduction}

Experimental influenza virus infection (EIVI) induces oxidative stress in the whole organism (Halliwell, 1994). It is accompanied with generation of reactive oxygen species (ROS) and lipid peroxides, inhibition of the 
antioxidant defense, alternations of the redox status and concentrations of different metal-protein complexes (Chetverikova and Inozemtseva, 1996; Peterhans, 1997a, b). These specific and nonspecific reactions cause accumulation of physiologically active metabolites, changes in biochemical pathways and pathology (Inozemtseva and Chetverikova, 1991; Peterhans, 1997b). The so caused acute inflammation, hypoxia and toxicosis result in hepatic oxidative damage (Meringova et al., 1996; Mileva et al., 2000). As far as the products of oxidative stress possess high cytotoxic activity, it is very important to study the molecular mechanisms of detoxication in the liver (effectiveness of the microsomal hydroxylation system - cytochrome P450, NADH-cytochrome $c$ reductase and the drug metabolizing enzyme system).

Flavonoids easily regulate the processes of free radical oxidation and oxidative stress induced by EIVI (Block and Langseth, 1994; Cook and Samman, 1996; De Groot and Rauen, 1998; Inozemtseva and Chetverikova, 1991). Their multiple biological effects are well established - anti-inflammatory, anti-allergic, anti-hemorrhagic, anti-mutagenic, anti-neoplastic and liver-protective activities (Block, 1992; Korkina and Afanas'ev, 1997; Hertog et al., 1993). Flavonoids and phenol acids are known for their antioxidant effects and appear effective antiviral drugs in the prevention of influenza but can inhibit the hepatic monooxygenase activities and induce oxidative damage (Crogt, 1998; Horvathova et al., 2001; Petica et al., 1994; Nagai et al., 1992; Esanu et al., 1981).

The aim of this work is to study the effect of rutin and quercetin on the hepatic monooxygenase system (microsomal hydroxylation and drug metabolism) in EIVI.

\section{Materials and methods}

\section{Animals and treatment}

The used animals are albino male mice, line ICR, initial body weight $14-16 \mathrm{~g}$, fasted for $12 \mathrm{~h}$ before the experiment. Animals are treated with rutin, quercetin or their combination $(20 \mathrm{mg} / \mathrm{kg}$ body weight). They are divided into following groups:

Group I: control (healthy animals), $n=15$

Group II: mice, infected with influenza virus A/Aichi/ $2 / 68$ (H3N2)-(1.5 of $\left.\mathrm{LD}_{50}\right)$ by intranasal inoculation, $n=15$

Group III: healthy mice, intraperitoneally injected with rutin, $n=15$

Group IV: healthy mice, intraperitoneally injected with quercetin, $n=15$
Group V: healthy mice, intraperitoneally injected with rutin and quercetin, $n=15$

Group VI: influenza infected mice, intraperitoneally injected with rutin, $n=15$

Group VII: influenza infected mice, intraperitoneally injected with quercetin, $n=15$

Group VIII: influenza infected mice, intraperitoneally injected with rutin and quercetin, $n=15$

Flavonoids are injected 3 days before and 2 days after the influenza viral inoculation. Mice are decapitated on the 5th day after the viral inoculation. No anesthesia is applied.

\section{Biological material}

Animal tissues (lungs, liver and brain) are in situ perfused with $1.15 \% \mathrm{KCl} / 4{ }^{\circ} \mathrm{C}$ solution. Then $33 \%$ tissue homogenates are prepared with $0.1 \mathrm{M}$ phosphate buffer $\left(\mathrm{pH} 7.4 / 37^{\circ} \mathrm{C}\right)$. Those are used for the measurements of thiobarbituric acid reactive substances (TBARS). S9 supernatants are used for all estimations of the monooxygenase systems. They are prepared after separation of the nuclei and mitochondrial fractions at $9000 \mathrm{~g} / 4^{\circ} \mathrm{C} / 20 \mathrm{~min}$ (H-24 centrifuge) from $33 \%$ liver tissue homogenate.

Venous blood from decapitated animals is collected in sterilized and heparinized $(1 \%)$ tubes. Blood plasma fractions are separated for the estimations of the reactive substance of the thiobarbituric acid.

TBARS are measured according to the modified method of Yagi (1976). About $0.2 \mathrm{ml}$ blood plasma/ $33 \%$ tissue homogenate are mixed to $0.1 \mathrm{ml} 0.9 \% \mathrm{NaCl}$. The first extraction of total lipid is according to Folch et al. (1957) in 2:1 (v/v) chloroform-methanol mixture. The received mixture is centrifuged at $1500 \mathrm{~g} / 2 \mathrm{~min}$. The fluorescent signal is measured at $\lambda=515 \mathrm{~nm}$ (excited state) and $\lambda=565 \mathrm{~nm}$ (fluorescent state). Each measurement is compared to automatically calibrated standard of malone-dialdehyde (MDA). The samples for estimation of the fluorescent MDATBARS contained: $0.5 \mathrm{ml}$ homogenate, $0.5 \mathrm{ml} \quad 0.67 \%$ TBA, $0.5 \mathrm{ml} 30 \%$ 3-chloracetic acid. All measurements are made with fluorometer "Hitachi-201".

\section{Monooxygenase enzyme activities}

\section{Cytochrome P-450 and NADPH-cytochrome $c$-reductase activities}

The content of hepatic cytochrome P-450 is measured with the method of Matsubara et al. (1976) and NADPH-cytochrome $c$-reductase - according to Roering et al. (1972). 


\section{Drug metabolizing enzyme system}

Monooxygenase hydroxylation activities with specific substrates - amidopyrine (aminopyrine $N$-demethylase APND) and analgin (analgin $N$-demethylase - ANND) are measured according to the method of Nash (1953).

Protein content in the blood plasma and homogenates is measured according to the method of Lowry et al. (1951).

Chemicals and reagents (analytical grade) are purchased from Merck (Germany) and Sigma-Aldrich (USA).

\section{Statistical analysis}

The statistics of all experimental data is performed according to the Student-Fisher's $t$-test. Data are presented as mean values \pm SEM. Reliable differences are accepted up to $P \leqslant 0.05$.

\section{Results and discussion}

EIVI activates the generation of ROS and free radicals, causing oxidative stress in the whole organism. This is registered in the blood plasma of infected animals where the concentration of TBARS is increased more than three times on 5th day after the viral inoculation. The preliminary treatment with rutin diminishes the concentration of lipid peroxidation (LPO) products only $10 \%$ and that with quercetin $-25 \%$. The complex application of both flavonoids decreases the LPOcontent $30 \%$. The antioxidant effect of quercetin is twice higher than the one of rutin (Fig. 1A).

Lungs are the target organ of the influenza virus. There are observed dynamic changes in oxidative metabolism, provoked by the generation of ROS and activation of neutrophils (Peterhans, 1997b). The concentration of LPO-products in the lungs of influenzainfected mice is rapidly increased - up to $290 \%$. Both natural flavonoids exhibit strong effect in this organ. The preliminary application of rutin decreases the content of TBARS $30 \%$ and the administration of quercetin $-40 \%$; their combination $-45 \%$ (Fig. 1B).

EIVI also results in brain oxidative stress. The concentration of TBARS is increased by about $50 \%$. Rutin and quercetin exhibit slight antioxidant effect in the brain of influenza-infected animals (Fig. 1C). Even low concentrations of oxidative stress products could pass the hemo-encephal barrier (Prilipko et al., 1983).

Influenza virus induces strong hepatic oxidative damage (Maeda and Akaike, 1991). The content of TBARS is increased up to $230 \%$. The application of quercetin results in $40 \%$ suppression of the free radical oxidation. Rutin shows three times weaker effect. The combined administration of both flavonoids presents additive inhibitory effect $-50 \%$ (Fig. 1D).
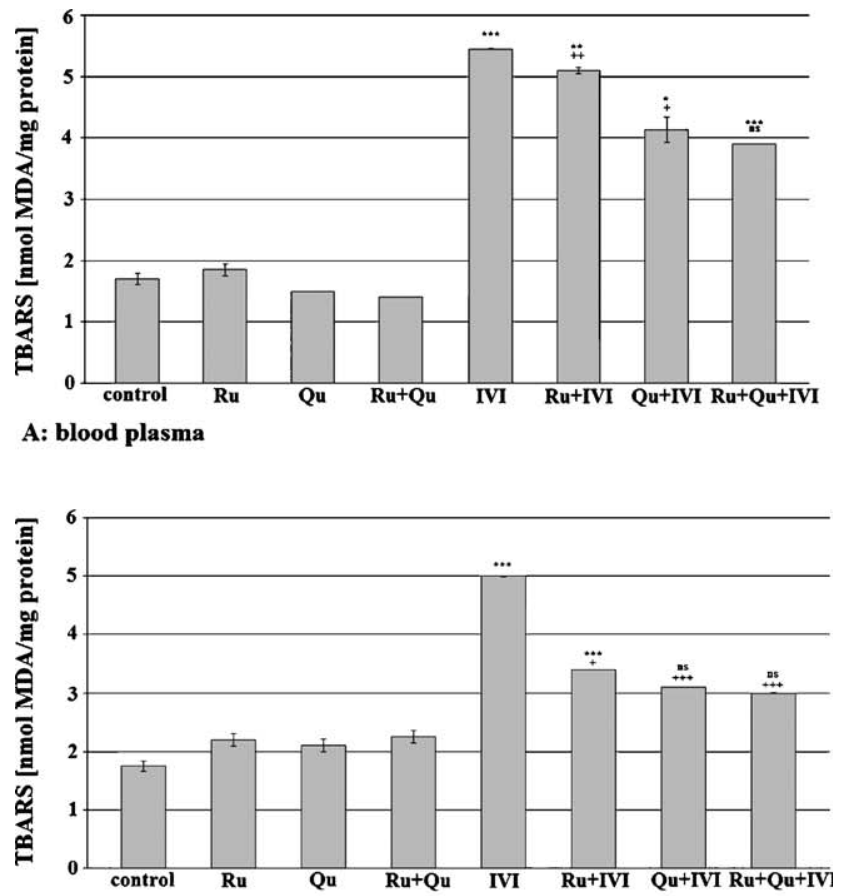

B: lungs

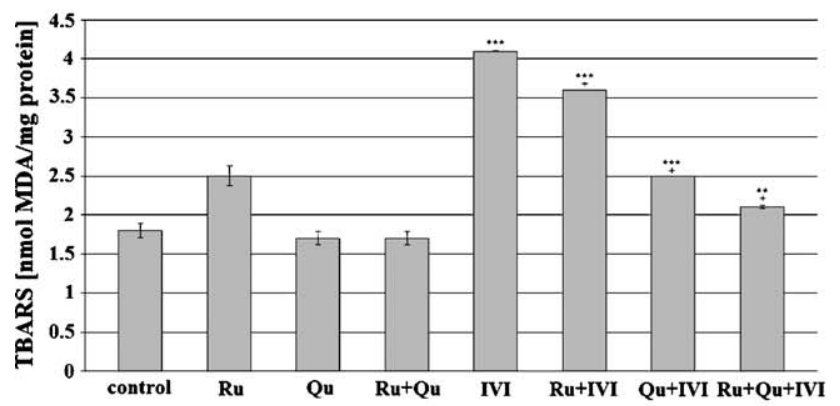

C: liver

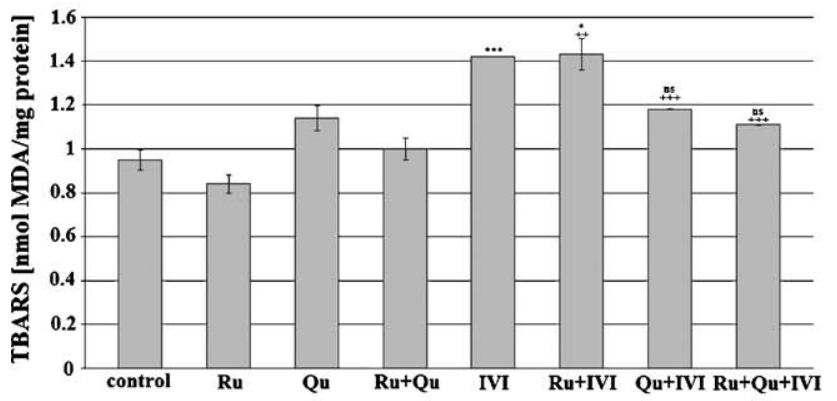

D: brain

Fig. 1. Concentrations of fluorescent LPO-products (TBARS) in the blood plasma (A), lungs (B), brain (C) and liver (D) in mice, treated with rutin $(\mathrm{Ru})$, quercetin $(\mathrm{Qu})$ and their combination $(\mathrm{Ru}+\mathrm{Qu})(20 \mathrm{mg} / \mathrm{kg}$, b.w.), on 5th day of experimental influenza virus infection (EIVI): 1, control (healthy animals); 2, control $(\mathrm{Ru})$; 3, control $(\mathrm{Qu})$; 4, control $(\mathrm{Ru}+\mathrm{Qu})$; 5, EIVI; 6, $\mathrm{EIVI}+\mathrm{Ru} ; 7$, EIVI $+\mathrm{Qu} ; 8$, EIVI $+\mathrm{Ru}+\mathrm{Qu} .{ }^{*} P<0.05$ versus group; $1 * * P<0.01$ versus group; $1 * * * P<0.001$ versus group 1 ; ns, non-significant. ${ }^{\dagger} P<0.05$ versus group 4 ; ${ }^{\dagger} P<0.01$ versus group $4 ;{ }^{\dagger \dagger} P<0.001$ versus group 4. 
The generation of ROS and radical intermediates also cause structural and functional alternations in the terminal components of the microsomal hydroxylation system of the liver - cytochrome P-450 and NADPHcytochrome $c$ reductase (Fig. 2).

The pretreatment of healthy animals with these flavonoids decreases to great extent the concentration of cytochrome P-450: rutin - 4.2, quercetin - 3.2, combination -2.4 times (Fig. 2A). EIVI causes more than 1.5-fold suppression of cytochrome P-450 on 5th day after the inoculation. Rutin stimulates the content of cytochrome P-450 only $13 \%$ in comparison to infected animals, quercetin $-30 \%$, their combination $22 \%$. This biphasic prooxidant/antioxidant activity of rutin and quercetin in healthy and infected organism is also observed in other investigations (Hodek et al., 2002). Probably, it depends on the specific stechiometry of their metabolites as well as on the applied concentrations (Ha et al., 1995; Sousa and Marletta, 1985). It is known that some flavonoids possess mutagenic and/or prooxidant effects and can interfere with essential biochemical pathways (Tsyrlov et al., 1994). It is established that flavonoids induce the expression of several cytochromes and modify (inhibit or stimulate)
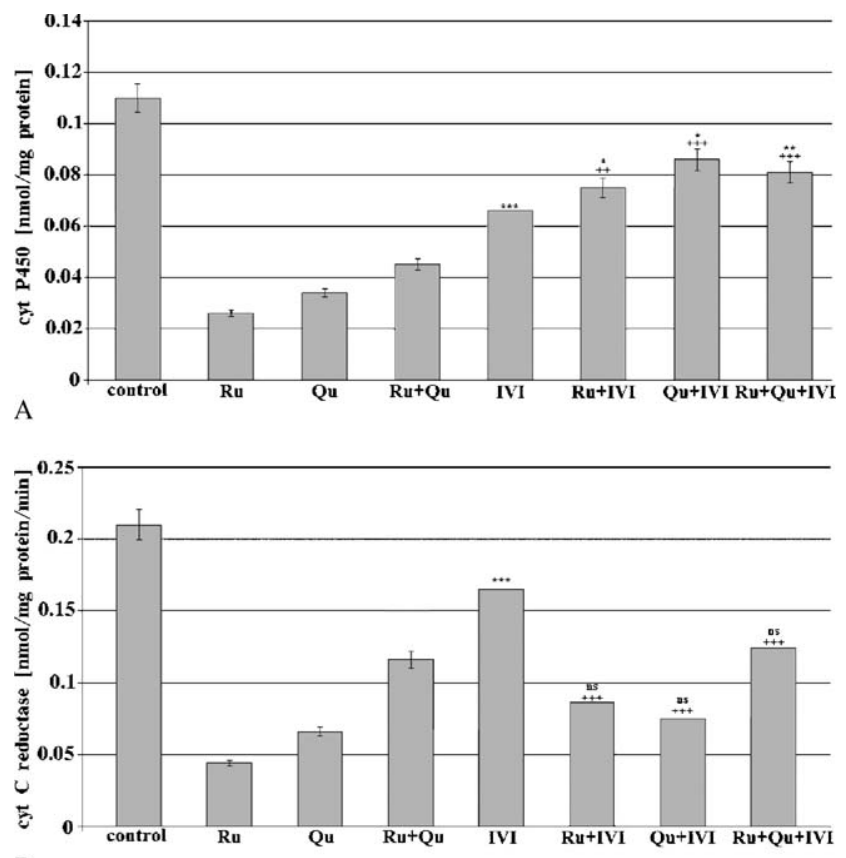

B

Fig. 2. Concentrations of cytochrome P-450 (A) and activity of NADPH-cytochrome $c$ reductase (B) in the liver of mice, treated with rutin $(\mathrm{Ru})$, quercetin $(\mathrm{Qu})$ and their combination $(\mathrm{Ru}+\mathrm{Qu})(20 \mathrm{mg} / \mathrm{kg}$, b.w.), on 5th day of experimental influenza virus infection (EIVI): 1, control (healthy animals); 2, control (Ru); 3, control (Qu); 4, control (Ru+Qu); 5, EIVI; 6, EIVI $+\mathrm{Ru} ; 7$, EIVI $+\mathrm{Qu} ; 8$, EIVI $+\mathrm{Ru}+\mathrm{Qu} .{ }^{*} P<0.05$ versus group $1 ; * * P<0.01$ versus group $1 ; * * * P<0.001$ versus group 1; ns, non-significant. ${ }^{\dagger} P<0.05$ versus group 4; ${ }^{\dagger} P<0.01$ versus group $4 ;{ }^{\dagger \dagger} P<0.001$ versus group 4 . their metabolic activity (Hodek et al., 2002). The analysis of the experimental data inclines negative correlations between the content of TBARS and the concentration of cytochrome P-450 in EIVI (Figs. 1 and 2). Achieved data demonstrate that high concentrations of LPO-products lead to degradation of cytochrome P450 and those flavonoids could partially restore the activity of this system only in influenza infected organism.

Rutin and quercetin affect the activity of NADPHcytochrome $c$ reductase. The application of rutin in healthy animals results in almost five times decrease, the one of quercetin - more than three times inhibition and their combination exhibits two-fold depletion (Fig. 2B). EIVI inhibits the activity of NADPH-cytochrome $c$ reductase by more than $20 \%$. Rutin and quercetin show, respectively, $48 \%$ and $55 \%$ deactivation, their combination - about $25 \%$ suppression in the influenza-infected animals (Fig. 2B). Experimental results show that rutin and quercetin possess no therapeutic effect on NADPHcytochrome $c$ reductase in both healthy and influenzainfected organism. These results are supported by other data, registering that quercetin could inhibit hepatic monooxygenase systems (Tsyrlov et al., 1994; Siess and Vernevaut, 1982).

Similar damage induced by influenza and oxidative stress is also observed on the activity of the hepatic drug metabolizing enzyme system with its demethylase substrates (analgin and amidopyrine).

Rutin suppresses more than $50 \%$ the activity of amidopyrine- $N$-demethylase (APND) in healthy animals, quercetin $-45 \%$, their combination - $60 \%$ (Fig. 3A). EIVI slightly induces the activity of APND. Rutin inhibits this drug metabolizing system in influenza-infected mice about $40 \%$, quercetin $-10 \%$ and their combination shows no effect (Fig. 3A).

The flavonoids rutin and quercetin strongly suppress the activity of analgin- $N$-demethylase (ANND) in healthy and influenza-infected mice. Strongest inhibition is performed by their combination in healthy animals (4.6 times). EIVI decreases the ANND enzyme activity with $35 \%$. Rutin shows almost three-fold suppression of this drug metabolizing system in infected animals, quercetin $-25 \%$, their combination $-25 \%$ (Fig. 3B).

No dead animals are registered until the 5th day of EIVI. But after the decapitation of influenza-infected mice are observed marked changes in the lungs and liver morphology: epithelial damage with areas of reactive hyperplasia; infiltration of leukocytes as a result from enhanced LPO and oxidative stress. Such effects are also observed by Kumar et al. (2003). The administration of rutin and especially quercetin cause positive therapeutic effect on morphological damages in the examined organs (Petica et al., 1994).

It is established that all biological and pharmacological effects of the flavonoids are assumed to result 

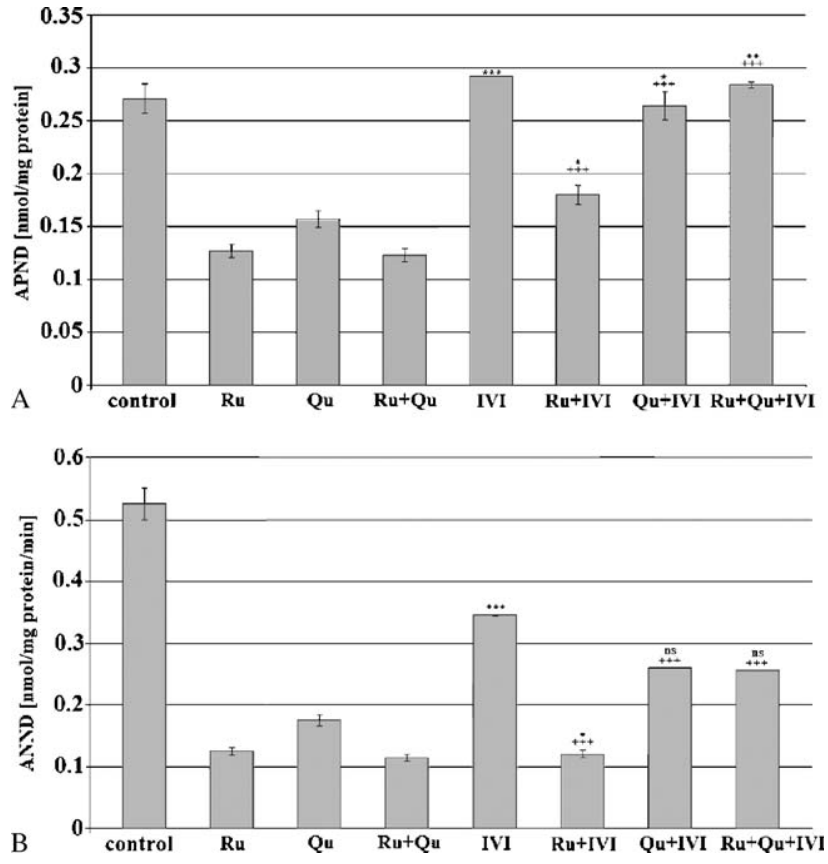

Fig. 3. Activity of the liver drug metabolizing enzyme system amidopyrine- $N$-demethylase (APND) (A) and analgin- $N$ demethylase (ANND) (B) in mice, treated with rutin $(\mathrm{Ru})$, quercetin $(\mathrm{Qu})$ and their combination $(\mathrm{Ru}+\mathrm{Qu})(20 \mathrm{mg} / \mathrm{kg}$, b.w.), on 5th day of experimental influenza virus infection (EIVI): 1, control (healthy animals); 2, control (Ru); 3, control $(\mathrm{Qu}) ;$ 4, control $(\mathrm{Ru}+\mathrm{Qu}) ;$ 5, EIVI; 6, EIVI $+\mathrm{Ru} ;$ 7, $\mathrm{EIVI}+\mathrm{Qu} ; 8, \mathrm{EIVI}+\mathrm{Ru}+\mathrm{Qu} .{ }^{*} P<0.05$ versus group 1; $* * P<0.01$ versus group $1 ; * * * P<0.001$ versus group 1 ; ns, non-significant. ${ }^{\dagger} P<0.05$ versus group $4 ;{ }^{\dagger} P<0.01$ versus group $4 ;{ }^{\dagger \dagger} P<0.001$ versus group 4 .

mainly from two properties: (i) direct and indirect inhibition of certain enzymes, including hexokinase, aldose reductase, phospholipase $c$, protein kinase $c$, cyclooxygenase, lypooxygenase, myeloperoxidase, NADPH oxidase and xantine oxidase (Middleton and Kandaswami, 1992) and (ii) their antioxidant activity. The antioxidant properties of flavonoid compounds are due to their ability to scavenge ROS and lipid radicals, to react with non-radical ROS, to form complexes with metal ions $\left(\mathrm{Fe}^{2+}, \mathrm{Cu}^{2+}\right)$ (Cotells, 2001; De Groot and Rauen, 1998; Guido et al., 1999; Korkina and Afanas'ev, 1997). These complexes are catalytically inactive, i.e. unable to catalyze the Fenton's reaction and formation of hydroxyl radicals.

Achieved data prove that EIVI is associated with oxidative stress in the whole organism. It causes strong depression on monooxygenase activities in the liver. Although known for their antioxidant activities, rutin and quercetin exhibit prooxidant effect in healthy and antioxidant activity in influenza diseased animals. Quercetin exhibits stronger antioxidant effect than rutin on the content of TBARS in the lungs, liver, brain and blood plasma of influenza-infected mice. Both flavo- noids exhibit stimulating effect on the level of cytochrome P-450 but inactivate NADPH-cytochrome $c$ reductase, APND and ANND activities on the 5th day of EIVI. Probably, rutin and quercetin affect different components of the monooxygenase system (Siess and Vernevaut, 1982). The inhibitory effect on monooxygenase activities could be explained with oxidative hepatic intoxication on the 5th critical day of EIVI as well as higher dose treatment. The biphasic effect of these flavonoids is due to complex factors - metabolic and physiological activities, including treatment of healthy or diseased organism, chemical structure, etc. Both are strongly recommended for treatment of infected organism but no influenza pretreatment and protection.

\section{References}

Block G. Role of antioxidants in reducing cancer risk. Nutr Rev 1992;50:207-13.

Block G, Langseth L. Antioxidant vitamins and disease prevention. Food Technol 1994;7:80-4.

Chetverikova LK, Inozemtseva LI. Role of lipid peroxidation in the pathogenesis of influenza and search for antiviral protective agents. Vestn Ross Akad Med Nauk 1996;3: 37-40.

Cook NC, Samman S. Flavonoids, chemistry, metabolism, cardioprotective effects and dietary sources. J Nutr Biochem 1996;7:66-76.

Cotells N. Role of flavonoids in oxidative stress. Curr Top Med Chem 2001;1(6):569-90.

Crogt KD. The chemistry and biological effects of flavonoids and phenolic acids. Ann NY Acad Sci 1998:435-42.

De Groot H, Rauen U. Tissue injury by reactive oxygen species and the protective effects of flavonoids. Fund Clin Pharmacol 1998;12:249-55.

Esanu V, Prahoveanu E, Crisan I, Cioca A. The effect of an aqueous propolis extract, rutin and rutin-quercetin mixture in experimental influenza virus infection. Virologie 1981; 32(3):213-5.

Folch J, Less M, Shoane-Stoaley CH. A simple method for the isolation and purification of total lipid from animal tissue. J Biol Chem 1957;226:497-507.

Guido RM, Haenen M, Bast A. Nitric oxide radicals scavenging of flavonoids. Methods Enzymol 1999;31: 490-503.

Ha HR, Chen J, Leuenberger PM, Freiburghaus AU, Follath F. In vitro inhibition of midazolam and quinidine metabolism by flavonoids. Eu J Clin Pharmacol 1995;48: 367-71.

Halliwell B. Free radicals, antioxidants and human disease: curiosity, cause or consequence? Lancet 1994;344:721-4.

Hertog MGL, Feskens EJM, Hollman PCH, Katan MB, Kromhout D. Dietary antioxidant flavonoids and risk of coronary heart disease, The Zutphen elderly study. Lancet 1993;342:1007-11.

Hodek P, Trefll P, Stiborova M. Flavonoids-potent and versatile biologically active compounds interacting with cytochromes P-450. Chem Biol Interact 2002;139(1):1-21. 
Horvathova K, Vachalkova A, Novotny L. Flavonoids as chemoprotective agents in civilization diseases. Neoplasma 2001;48:435-41.

Inozemtseva LI, Chetverikova LK. The role of lipid peroxidation in post-stress aggravation of influenza and corrective effect of ionol. Vestn Acad Nauk SSSR 1991;4:54-7.

Korkina LG, Afanas'ev IB. Antioxidant and chelating properties of flavonoids. In: Sies $\mathrm{H}$, editor. Advances in pharmacology. San Diego: Academic Press; 1997. p. 151-63.

Kumar P, Sharma S, Khanna M, Raj HG. Effect of quercetin on lipid peroxidation and changes in lung morphology in experimental influenza virus infection. Int $\mathbf{J}$ Exp Pathol 2003;84(3):127-33.

Lowry O, Rosenbrough N, Farr A, Randall R. Protein measurement with the Folin phenol reagent. J Biol Chem 1951;193:265-72.

Maeda H, Akaike T. Oxygen free radicals as pathogenic molecules in viral diseases. Proc Soc Exp Biol Med 1991;198(2):721-7.

Matsubara N, Koilke M, Touchi A, Tochino Y, Sugeno K. Quntative determination of cytochrome P-450 in rat liver homogenate. Anal Biochem 1976;75(2):596-603.

Meringova LF, Kramskala TA, Dukhin AI, Iakovleva IV, Chetverikova LK, Poliak RA. Effects of antioxidant ionol on humoral immune response in experimental influenza. Vestn Ross Akad Med Nauk 1996;3:34-7.

Middleton E, Kandaswami C. Effects of flavonoids on immune and inflammatory cell function. Biochem Pharmacol 1992;43:1167-79.

Mileva M, Tancheva L, Bakalova R, Galabov A, Savov V, Ribarov S. Effect of vitamin $\mathrm{E}$ on lipid peroxidation and liver monooxygenase activity in experimental influenza virus infection. Toxicol Lett 2000;114:39-45.

Nagai T, Miyaichi Y, Tomimori T, Suzuki Y, Yamada H. Invivo anti-influnza virus activity of plant flavonoids posses- sing inhibitory activity for influenza virus sialidase. Antiviral Res 1992;19(3):207-17.

Nash T. The colorimetric estimation of formaldehyde by means of the Hautch reaction. J Biol Chem 1953;55: 416-22.

Peterhans E. Oxidants and antioxidants in viral diseases: disease mechanisms and metabolic regulation, symposium: newly emerging viral diseases: what role for nutrition? Am Soc Nutr Sci 1997a(Suppl.):962-5.

Peterhans E. Reactive oxygen species and nitric oxide in viral diseases. Biol Trace Elem Res 1997;56(1):107-16.

Petica M, Crisan I, Esanu V, Petresku A. Morphologic changes following experimental influenza virus infection and the therapeutic administration of flavonoids in aqueous extracts. Rev Roum Virol 1994;45(1-2):39-45.

Prilipko LL, Savov VM, Kagan VE. Activation of lipid peroxidation: a mechanism triggering the autoimmune response. Acta Physiol Pharmacol Bulgarica 1983;9(4): 14-20.

Roering D, Mascaro L, Aust S. Microsomal electron transport: tetrafolium reduction by rat liver microsomal NADPH-cytochrome $c$-reductase. Arch Biochem 1972; 153:475-9.

Siess MH, Vernevaut MF. The influence of food flavonoids on the activity of some hepatic microsomal monooxygenases in rats. Food Chem Toxicol 1982;20(6):883-6.

Sousa RL, Marletta MA. Inhibition of cytochrome P-450 activity in rat liver microsomes by the naturally occurring flavonoid, quercetin. Arch Biochem Biophys 1985;240(1): 345-57.

Tsyrlov IB, Mikhailenko VM, Gelboin HV. Izoenzyme- and species-specific susceptibility of cDNA-expressed CYP1A P-450s to different flavonoids. Biochem Biophys Acta 1994;1205(2):325-35.

Yagi K. A simple fluorimetric assay for lipoperoxide in blood plasma. Biochem Med 1976;15:212-6. 